\title{
ADIASPORES OF Emmonsia parva var. crescens IN LUNGS OF SMALL RODENTS IN A RURAL AREA
}

\author{
O. A. FISCHER \\ Bohuslava Martinů 44, Brno, Czech Republic \\ Received February 26, 2001 \\ Accepted May 28, 2001
}

Abstract

Fischer O. A.: Adiaspores of Emmonsia parva var. crescens in Lungs of Small Rodents in a Rural Area. Acta Vet. Brno 2001, 70: 345-352.

The purpose of this study was to compare the occurrence of Emmonsia parva var. crescens in populated and unpopulated habitats of a rural area (in a village with 615 inhabitants and in surrounding forests without human population) as indicated by findings of adiaspores in lungs of small rodents captured in these habitats. Adiaspores of E. parva var. crescens were found in lungs of $13(9.6 \%)$ out of 135 examined rodents. Four rodent species out of 7 were infected: the bank vole (Clethrionomys glareolus, $15.6 \%$ ), the house mouse (Mus musculus, $5.6 \%$ ), the wood mouse (Apodemus sylvaticus, $3.2 \%$ ) and the yellow-necked field mouse (A. flavicollis, $16.7 \%$ ). The highest prevalence was found in the A. flavicollis and in the $C$. glareolus in the village and in the forests, respectively. Intensity of the infection was low or moderate (below 100 adiaspores per animal). The highest prevalence of the infection was found in spring. The prevalence was not influenced by sex of the animals. Occurrence of both saprophytic stage of E. parva var. crescens and rodents can be enabled by plant cover of uncultivated soil in the village, where the same plant species as in the surrounding forests occur. Therefore the risk of infection for humans and animals is not limited only to forest (unpopulated) habitats.

Sapronoses, emmonsiosis, Arvicolidae, Muridae, Czech Republic

Emmonsiosis (adiaspiromycosis) is a world-wide distributed, largely neglected and underdiagnosed pulmonary disease of mammals, including humans (Hu bálek et al. 1998). Only one causative agent of emmonsiosis, the fungus Emmonsia parva var. crescens (Emmons et Jellison 1960 van Oorschot1980), occurs in the Czech Republic (Dvořák et al. 1973). The infection is widespread especially among rodents of the families Arvicolidae and Muridae (Hubálek et al. 1991) and more rarely in the families Sciuridae (Křivanec et al. 1976) and Cricetidae (Hubálek 1999). The source of infection is the saprophytic stage of fungus producing minute conidia. After inhalation of the conidia by mammalian host, large thick-walled spherules called adiaspores develop in host tissues, most often in lungs. Expanding adiaspore, a parasitic stage of the fungus, causes inflammatory reaction in lung tissue (Kod'ousek et al. 1971; Halouzka et al. 1989; Ooi and Lin 1996), which leads to collapse of the adjacent alveoli resulting, in case of massive infection, to respiratory distress or even lung failure (Hubálek 1999). Macroscopic pathomorphological changes are densely disseminated whitish nodules about 1 to $2 \mathrm{~mm}$ in diameter, described by Kod'ou sek et al. (1971) in a case human emmonsiosis. After death of the infected host, the saprophytic stage can grow from the adiaspores released from dead host's body (Křivanec and Otčenášek 1977). Although the main source of conidia is the soil (Dvořák et al. 1973; Prokopič and Štěrba 1978), conditions of natural infection were not studied sufficiently. Because of danger for humans (Kodousek et al. 1971; England and Hochholzer 1993; Nuorva et al. 1997; de Montpréville et al. 1999) and close taxonomic relations of Emmonsia to other pathogenic fungi of the anamorphous genera Paracoccidioides, Blastomyces and Histoplasma (Peterson and Sigler 1998) emmonsiosis was studied by many biologists, mycologists and microbiologists, but no 
complete information about all possible routes of infection and health hazard for humans and animals in densely populated areas, such as in villages and towns, is available. Most studies have been hitherto performed in exoanthropic habitats. Village ecosystem includes not only intensively cultivated arable fields, orchards and gardens, which are not suitable for growing of the saprophytic stage (Hubálek et al. 1998), but also uncultivated areas with weeds, such as nettle (Urtica spp.) and common elder (Sambucus nigra), and wet, shady places, enabling growth of the saprophytic stage of the fungus.

The aim of this study was to compare the occurrence of Emmonsia infection in village and forest habitats as indicated by findings of adiaspores in lungs of small rodents of the families Arvicolidae and Muridae.

\section{Materials and Methods}

Area under study

South-Moravian village Ketkovice near Brno (N 490' E 16º6', quadrat 6863 of the national faunal mapping grid) with 615 inhabitants is situated $35 \mathrm{~km}$ west of Brno and $5 \mathrm{~km}$ from west margin of Rosice-Oslavany Black Coal Basin in forest-arable hilly land at average elevation $433 \mathrm{~m}(340-480 \mathrm{~m})$ a.s.1. (Fischer 2000). The road from Rapotice to Oslavany passing through the village makes a frontier of nature reservation Oslava. The right (southwest) half of the village with adjacent pieces of land (fields and forests) belongs to the reservation, the left (northeast) one does not belong to this reservation. The climate is cold and dry, with average annual precipitation below $600 \mathrm{~mm}$ and drinking water deficits. The annual mean temperature is $7.5^{\circ} \mathrm{C}\left(\mathrm{January}-5^{\circ} \mathrm{C}\right.$, July $20^{\circ} \mathrm{C}$ ). The average year thickness of snow cover is less than $0.5 \mathrm{~m}$. The air is polluted mostly by thermal powerplant and incinerator in Oslavany ( $7 \mathrm{~km}$ from Ketkovice). There are arable fields with potatoes, alfalfa, turnip, rye, wheat, barley, oat, intensively cultivated meadows, orchards and gardens around the village (Fischer 2000), but also uncultivated soil with weeds. The village is surrounded with spruce (Picea abies, Pinus silvestris) and deciduous (Carpinus betulus, Quercus spp.) forests in a distance $250-1000 \mathrm{~m}$ from the margins of the village. Small brook (Ketkovický potok) rises in the northern margin and flows through the centre of the village to the southeast. Another small brook (Balinka) rises $100 \mathrm{~m}$ from north-eastern margin of the village and flows far away to southeast. In the village, the rodents were caught in a house at the eastern margin of the village. The miner family house built in 1932 had three rooms, a shed, a former hen-house, two yards, a small alfalfa field and a small garden. The nearest forest margin is about $1000 \mathrm{~m}$ from the house (Fis cher 2000). No poultry or domestic animals were kept in this house, but rabbits, poultry, cats, dogs, pigs and goats were kept in neighbouring barns, and a cow-shed with about 200 cows was at the western margin of the village, only $250 \mathrm{~m}$ from a forest. A stone marten (Martes foina Erxleben, 1777) lived in loft of the house at this time.

Collection and examination of rodents

Small rodents were caught in snap-traps in the village house and in surrounding forests from July 3,1999 to November 3, 2000. Captured rodents were determined, sexed and dissected. Macroscopic examinations of lungs were performed during dissections and special attention was given to any nodules in lung tissue. Whole lungs were preserved in $10 \%(\mathrm{v} / \mathrm{v})$ water solution of formaldehyde. They were warmed in the formaldehyde solution to $80^{\circ} \mathrm{C}$ for 30 minutes and after cooling to $40{ }^{\circ} \mathrm{C}$ prior the examination. Then they were exposed to $2 \%$ (w/v) water solution of sodium hydroxide $\mathrm{NaOH}$ for $3 \mathrm{~h}$. Compression preparations of small pieces of lungs were examined microscopically at a standard magnification $32 \times$. Usually 10 slides were prepared from the whole lungs of one animal. All adiaspores were measured. Only adiaspores with diameters above $70 \mu \mathrm{m}$ were determined as E. parva var. crescens and counted. Intensity of infection was assessed as low (1 to 9 adiaspores), moderate (10 to 99 adiaspores), high (100 to 999 adiaspores) and very high (1000 or more adiaspores per animal) according to Hu bálek (1999).

Plant species composition

Special attention was given to occurrence of the most abundant plants in both habitats of the study area (Fau stus and Polívka 1976).

Statistics

Student's $t$-test was used to evaluate average numbers of adiaspores in animal species and mean diameters of adiaspores (Table 2). Differences in the prevalence of infection (Tables 1 and 3) were evaluated by the Fisher's exact test (Venčikov and Venčikov 1977).

\section{Results}

No macroscopic pathomorphological changes in lungs of trapped animals were observed and no nodules resembling Emmonsia granulomas were found. All adiaspores were found 
Table 1

Findings of adiaspores of Emmonsia parva var. crescens in lungs of small rodents by their habitats

\begin{tabular}{|c|c|c|c|c|c|c|}
\hline \multirow[t]{2}{*}{ Hosts } & \multicolumn{2}{|l|}{ Village } & \multicolumn{2}{|l|}{ Forests } & \multicolumn{2}{|c|}{ Both habitats } \\
\hline & Positive/examined & $\%$ & Positive/examined & $\%$ & Positive/examined & $\%$ \\
\hline $\begin{array}{l}\text { Bank vole } \\
\text { (Clethrionomys glareolus } \\
\text { Schreber, 1780) }\end{array}$ & $0 / 5$ & 0 & $7 / 40$ & 17.5 & $7 / 45$ & 15.6 \\
\hline $\begin{array}{l}\text { Common vole } \\
\text { (Microtus arvalis } \\
\text { Pallas, 1779) }\end{array}$ & $0 / 14$ & 0 & $0 / 0$ & 0 & $0 / 14$ & 0 \\
\hline $\begin{array}{l}\text { Short-tailed vole } \\
\text { (M. agrestis } \\
\text { Linnaeus, 1761) }\end{array}$ & $0 / 0$ & 0 & $0 / 1$ & 0 & $0 / 1$ & 0 \\
\hline $\begin{array}{l}\text { House mouse } \\
\text { (Mus musculus } \\
\text { Linnaeus, 1758) }\end{array}$ & $1 / 18$ & 5.6 & $0 / 0$ & 0 & $1 / 18$ & 5.6 \\
\hline $\begin{array}{l}\text { Wood mouse } \\
\text { (Apodemus sylvaticus } \\
\text { Linnaeus, 1758) }\end{array}$ & $0 / 19$ & 0 & $1 / 12$ & 8.3 & $1 / 31$ & 3.2 \\
\hline $\begin{array}{l}\text { Yellow-necked field mouse } \\
\text { (A. flavicollis } \\
\text { Melchior, 1834) }\end{array}$ & $2 / 9$ & 22.2 & $2 / 15$ & 13.3 & $4 / 24$ & 16.7 \\
\hline $\begin{array}{l}\text { Herb field mouse } \\
\text { (A. microps } \\
\text { Kratochvíl et Rosický, 1952) }\end{array}$ & $0 / 0$ & 0 & $0 / 2$ & 0 & $0 / 2$ & 0 \\
\hline Total & $3 / 65$ & 4.6 & $10 / 70$ & 14.3 & $13 / 135$ & 9.6 \\
\hline
\end{tabular}

in compression preparations only. A total of $13(9.6 \%)$ rodents out of 135 examined were infected (Table 1). Four out of 7 species of rodents were infected: Clethrionomys glareolus (15.6\%), Mus musculus (5.6\%), Apodemus sylvaticus (3.2\%) and A. flavicollis (16.7 \%). Two rodent species, $M$. musculus and A. flavicollis, were infected in the village and three species, $C$. glareolus, A. sylvaticus and A. flavicollis, were infected in the forests. $C$. glareolus from the forests $(17.5 \%)$ was more often infected than A. flavicollis from the same habitat $(13.3 \% ; P>0.05$, non-significant). A. flavicollis was more often infected $(P>0.05)$ in the village $(22.2 \%)$ than in the forests $(13.3 \%)$. A. flavicollis in the village $(22.2 \%)$ was more infected $(P>0.05)$ than $C$. glareolus in the forests $(17.5 \%)$. A. flavicollis was also in total more frequently infected than $C$. glareolus $(16.7 \%$ vs. $15.6 \% ; P>0.05)$. In total, rodents captured in the forests $(14.3 \%)$ were significantly $(P=0.04)$ more frequently infected than rodents from the village $(4.6 \%)$.

The smallest adiaspore $(83 \mu \mathrm{m})$ and the largest one $(575 \mu \mathrm{m})$ were found in one M. musculus captured in the village in August and in a $C$. glareolus captured in the forest in June, respectively. Intensity of the infections was low to moderate (Table 2). Two moderate infections, 27 and 36 adiaspores per one host, were found in two A. flavicollis captured in the forests in March and April, respectively. A. flavicollis captured in the forests had significantly greater number of adiaspores than $A$. flavicollis captured in the village $(P<0.01)$. Average diameters of adiaspores were greater $(P<0.01)$ in $A$. flavicollis from the village $(282.1 \pm 34.5 \mu \mathrm{m})$ than in A. flavicollis from the forests $(205.9 \pm 46.6 \mu \mathrm{m})$.

In total, adiaspores were found more often $(P>0.05)$ in animals captured in spring 
Table 2

Intensity of Emmonsia infection in small rodents

\begin{tabular}{|c|c|c|c|c|c|}
\hline \multirow{3}{*}{$\begin{array}{l}\text { Total number of } \\
\text { adiaspores } \\
\text { found in one rodent } \\
\text { species } \\
\text { (average number } \\
\text { of adiaspores } \pm \text { S.D.) }\end{array}$} & Habitat & C. glareolus & M. musculus & A. sylvaticus & A. flavicollis \\
\hline & $\mathrm{V}$ & 0 & $\begin{array}{c}1 \\
(1.0 \pm 0.0)\end{array}$ & 0 & $\begin{array}{c}7 \\
(3.5 \pm 3.5)\end{array}$ \\
\hline & $\mathrm{F}$ & $\begin{array}{c}14 \\
(2.0 \pm 2.0)\end{array}$ & 0 & $\begin{array}{c}1 \\
(1.0 \pm 0.0)\end{array}$ & $\begin{array}{c}63 \\
(31.5 \pm 6.4)\end{array}$ \\
\hline \multirow{2}{*}{$\begin{array}{l}\text { Low intensity of infection } \\
\text { (No. of cases) }\end{array}$} & $\mathrm{V}$ & 0 & 1 & 0 & 2 \\
\hline & $\mathrm{F}$ & 7 & 0 & 1 & 0 \\
\hline \multirow{2}{*}{$\begin{array}{l}\text { Moderate intensity of } \\
\text { infection (No. of cases) }\end{array}$} & $\mathrm{V}$ & 0 & 0 & 0 & 0 \\
\hline & $\mathrm{F}$ & 0 & 0 & 0 & 2 \\
\hline \multirow{2}{*}{$\begin{array}{l}\text { Minimal - maximal number } \\
\text { of adiaspores per host }\end{array}$} & $\mathrm{V}$ & 0 & 1 & 0 & $1-6$ \\
\hline & $\mathrm{F}$ & $1-4$ & 0 & 1 & $27-36$ \\
\hline \multirow{2}{*}{$\begin{array}{l}\text { Average } \\
\text { diameter } \\
\text { of adiaspores } \\
\pm \text { S.D. } / \mu \mathrm{m} / \\
\text { (range) }\end{array}$} & $\mathrm{V}$ & 0 & $\begin{array}{c}83.0 \pm 0.0 \\
n=1\end{array}$ & 0 & $\begin{array}{c}282.1 \pm 34.5 \\
n=7 \\
(250-325)\end{array}$ \\
\hline & $\mathrm{F}$ & $\begin{array}{c}377.5 \pm 123.6 \\
n=14 \\
(245-575)\end{array}$ & 0 & $\begin{array}{c}400.0 \pm 0.0 \\
\mathrm{n}=1\end{array}$ & $\begin{array}{c}205.9 \pm 46.6 \\
n=63 \\
(125-325)\end{array}$ \\
\hline
\end{tabular}

C. - Clethrionomys, M. - Mus, A. - Apodemus, V - village, F-forest, $\mathrm{n}$ - number of measured adiaspores, S.D.= standard devation.

$(19.2 \%)$ than in winter $(10.0 \%)$ and in summer $(9.8 \%)$. The autumn prevalence $(4.2 \%)$ was not significantly lower than summer one $(\mathrm{P}>0.05$, Table 3$)$.

Emmonsia infection was uniformly distributed between males and females. Three (13.6 $\%$ ) out of 22 examined males and $4(17.4 \%)$ out of 23 examined females of $C$. glareolus were infected $(\mathrm{P}>0.05)$. Two $(20.0 \%)$ out of 10 examined males and $2(14.3 \%)$ out of 14 examined females of $A$. flavicollis were infected $(\mathrm{P}>0.05)$. No statistically significant diferences between prevalences in both sexes were found $(\mathrm{P}>0.05)$.

Table 3

Emmonsia infection in seasons of the year

\begin{tabular}{|c|c|c|c|c|c|c|c|c|}
\hline \multirow[t]{2}{*}{ Hosts } & \multicolumn{2}{|c|}{$\begin{array}{c}\text { Winter } \\
(\mathrm{XII}-\mathrm{II})\end{array}$} & \multicolumn{2}{|c|}{$\begin{array}{l}\text { Spring } \\
(\mathrm{III}-\mathrm{V})\end{array}$} & \multicolumn{2}{|c|}{$\begin{array}{c}\text { Summer } \\
(\mathrm{VI} \text { - VIII) }\end{array}$} & \multicolumn{2}{|c|}{$\begin{array}{l}\text { Autumn } \\
\text { (IX - XI) }\end{array}$} \\
\hline & P./E. & $\%$ & P./E. & $\%$ & P./E. & $\%$ & P./E. & $\%$ \\
\hline $\begin{array}{l}\text { Clethrionomys } \\
\text { glareolus }\end{array}$ & $1 / 7$ & 14.3 & $2 / 11$ & 18.2 & $3 / 23$ & 13.0 & $1 / 4$ & 25.0 \\
\hline Microtus arvalis & $0 / 4$ & 0 & $0 / 2$ & 0 & $0 / 0$ & 0 & $0 / 8$ & 0 \\
\hline M. agrestis & $0 / 0$ & 0 & $0 / 0$ & 0 & $0 / 0$ & 0 & $0 / 1$ & 0 \\
\hline Mus musculus & $0 / 0$ & 0 & $0 / 4$ & 0 & $1 / 11$ & 9.1 & $0 / 3$ & 0 \\
\hline Apodemus sylvaticus & $0 / 6$ & 0 & $1 / 5$ & 20.0 & $0 / 2$ & 0 & $0 / 18$ & 0 \\
\hline A. flavicollis & $1 / 3$ & 33.3 & $2 / 4$ & 50.0 & $0 / 3$ & 0 & $1 / 14$ & 7.1 \\
\hline A. microps & $0 / 0$ & 0 & $0 / 0$ & 0 & $0 / 2$ & 0 & $0 / 0$ & 0 \\
\hline Total & $2 / 20$ & 10.0 & $5 / 26$ & 19.2 & $4 / 41$ & 9.8 & $2 / 48$ & 4.2 \\
\hline
\end{tabular}

P. - number of positive hosts, E. - number of examined hosts. 
Twenty nine abundant plant species /14 herbs, 6 shrubs and 9 trees/ occurring in large numbers in forest habitat, village habitat or both were recorded. Sixteen plant species $/ 8$ herbs: Dryopteris filix-mas (family Polypodiaceae), Anemone nemorosa (Ranunculaceae), Alliaria officinalis (Brassicaceae), Rubus idaeus (Rosaceae), Oxalis acetosella (Oxalidaceae), Impatiens parviflora (Impatientaceae), Hypericum perforatum (Hypericaceae) and Epilobium parviflorum (Oenotheraceae), one shrub: Ligustrum vulgare (Oleaceae) and 7 trees: Picea abies, Larix decidua, Pinus silvestris (Pinaceae), Carpinus betulus, Betulla verucosa, Quercus robur (Betulaceae), Acer pseudoplatanus (Aceraceae)/ were the most abundant plant species in forest habitat. Three herb species /Thlaspi arvense (Brassicaceae), Urtica urens (Urticaceae) and Pastinaca sativa (Daucaceae)/ were the most abundant plant species in village habitat. Ten plant species $/ 3$ herbs: Chelidonium majus (Papaveraceae),Urtica dioica (Urticaceae), Daucus carota var. silvestris (Daucaceae), 5 shrubs: Rubus fruticosus, Rosa canina, Prunus spinosa (Rosaceae), Corylus avellana (Betulaceae), Sambucus nigra (Loniceraceae) and 2 trees: Robinia pseudoacacia (Viciaceae) and Tilia cordata (Tiliaceae)/ occurred in both habitats of the area under study.

\section{Discussion}

Hubálek et al. (1997) examined rodents of nine species in six localities near Ketkovice (quadrat 6863) in the vicinity of Moravský Krumlov. The most infected species were C. glareolus (20.9\%), A. sylvaticus (11.4\%) and A. flavicollis $(11.3 \%)$. They recorded also infection of $M$. arvalis $(11.0 \%)$ and one from five pine voles (M. subterraneus De SélysLongchamps, 1836). M. arvalis prefers fields and meadows. Most of individuals entering the house in Ketkovice originated from surrounding fields. Farmland habitats like arable fields, cultivated meadows, orchards and gardens are obviously less optimal than uncultivated habitats (woods, shrubby balks or windbreaks between fields) for the growth of Emmonsia in the soil. This resulted in a lower incidence of rodent emmonsiosis in the agrocenoses (Hubálek et al. 1995a). Growth requirements of saprophytic stage of E. parva var. crescens in nature have not been defined clearly. The most probable place of occurrence of saprophytic stage is wet soil in shady places (Hubálek et al. 1995b, 1998) and lairs of animals, especially rodents (Prokopič and Štěrba 1978). Hubálek et al. (1998) found a higher prevalence of the infection in adult rodents from windbreaks than in those from adjacent arable fields, $62.1 \%$ and $8.2 \%$, respectively. Occurrence of Emmonsia was not influenced by water content and $\mathrm{pH}$ values of the soil, but significantly higher mean weight proportion of plant remnants was present in the soil from windbreaks than from fields.

Among 29 most abundant plant species growing in Ketkovice and surrounding forests were ten species occuring in both habitats. C. majus, U. dioica and D. carota var. silvestris are shadow-tolerating herbs (Faustus and Polívka 1976). R. fruticosus, R. canina, $P$. spinosa, $C$. avellana and $S$. nigra are bushes producing large amount of plant remnants and they provide small rodents food (Holišová 1960; Abt 1992) and shelter. $R$. pseudoacacia and T. cordata are deciduous trees producing plant remnants (Faustus and Polívka 1976). Because these plants grow in both habitats, small rodent populations in village have similar living conditions as in the forests. In accordance with Hubálek et al. (1998), R. canina, S. nigra and T. cordata (growing also in the windbreaks) were found among plant species occurring in both habitats in Ketkovice near Brno.

Nu orva et al. (1997) described emmonsiosis in a two-year-old Finnish girl of Caucasian origin. Her mother worked in a large garden shop and she was in contact with soil therefore.

Prokopič and Štěrba (1978) infected white laboratory mice (house mouse, M. musculus) by keeping them in a territory previously used by a colony of common voles (M. arvalis) spontaneously infected with E. parva var. crescens. Adiaspores $190-210 \mu \mathrm{m}$ in diameter were found in lungs of mice after four months of inhabiting of former vole lairs. Rodents from air- 
polluted areas were more infected than rodents from non-polluted areas (Ječný and Vojtěchová 1984; Hubálek et al. 1988).

High prevalence (C. glareolus $45 \%$, A. flavicollis $56 \%$, A. sylvaticus $26 \%$, M. agrestis $13 \%$ and $M$. arvalis $9 \%$ ) in rodents inhabiting the shores of fishponds in district Třebíč (about $40 \mathrm{~km}$ from Ketkovice) was found by Hubálek et al. (1995b). There are no fishponds or large water sources in Ketkovice (Fischer 2000).

The highest prevalence of infection occurs in spring and winter (Hubálek et al. 1995b). Although the age of rodents was not assessed in present study, it is well-known that adult animals are more often infected than juveniles (Ječný and Vojtěchová 1984; Hubálek et al. 1988, 1997). Low autumn prevalence can be explained by the fact that rodent populations include many juvenile animals in the autumn (Rajska-Jurgiel 2000).

Emmonsia infection was not influenced by sex of animals. The same results reported Hubálek et al. (1988;1997).

Very low prevalence and intensity of infection in M. musculus can be explained by its synanthropy. Hemisynanthropic A. flavicollis was the most infected rodent species in the village and the second most infected species in the forests. The most infected species in the forests was the exoanthropic bank vole (C. glareolus). Similar relations were observed in mustelid carnivores of the family Mustelidae by Křivanec and Otčenášek (1977). Whereas exoanthropic pine marten (Martes martes Linnaeus, 1758) and steppe polecat (Putorius eversmanni Lesson, 1827) captured in the Czechoslovakia had a high prevalence, $72.2 \%$ and $70.3 \%$, respectively, hemisynanthropic stone marten (M. foina) and dark polecat (P. putorius Linnaeus, 1758) had lower prevalence, $37.5 \%$ and $30.6 \%$, respectively. Suitable living conditions for hemisynanthropic animals were indicated by presence of M. foina in house in Ketkovice during the study period.

No macroscopic pulmonary lesions were found in examined animals, because the intensity of infection was either low or moderate. Hubálek et al. (1988) found in lungs of one short-tailed vole (M. agrestis) from air-polluted area of Krušné hory (Ore Mountains, Bohemia) as many as 1130 adiaspores (very high intensity of infection), which undoubtedly influenced the health status of the animal.

Emmonsia infection was found not only in small rodents, but also in larger rodent species such as squirrel (Sciurus vulgaris Linnaeus, 1758) and muskrat (Ondatra zibethicus Linnaeus, 1758) in the Czech Republic (Křivanec et al. 1976; Hubálek 1999) and beaver (Castor fiber Linnaeus, 1758) in Sweden (Mörner et al. 1999). Křivanec et al. (1976) found infection in lungs of $36(20.5 \%)$ from 176 squirrels captured in many various parts of the Czechoslovakia. The diameters of adiaspores varied from 150 to $600 \mu \mathrm{m}$, but most frequent were diameters of $400-500 \mu \mathrm{m}$. Adiaspores found in the beaver by Mörner et al. (1999) were $100-200 \mu \mathrm{m}$ large.

The size of adiaspores indicates a probable time of infection of the host. Adiaspores of E. parva var. crescens reach a diameter of $130-230 \mu \mathrm{m}$ within one month, that of $220-420$ $\mu \mathrm{m}$ in two months after infection (Hubálek et al. 1988). According to these data, most of rodents were infected probably in autumn or winter.

Emmonsiosis is a neglected and underdiagnosed disease, because there are no suitable diagnostic methods. Small nodules can be overlooked or mistaken for other pathomorphological changes, for instance miliary tuberculosis (Kod'ousek et al. 1971; Johnstone et al. 1993). Cultivation of Emmonsia spp. is difficult (Dvořák et al. 1973; Křivanec and Otčenášek 1977) and serological dignostic methods are complicated by cross reactions with other soil fungi (Hubálek et al. 1998). Adiaspores can be easily demonstrated by histological staining methods. They are large, with a typical structure (Halouzka et al. 1989), and can be well stained with gallocyanine blue (Kod ou sek et al. 1971), PAS (Ooi and Lin 1996), Grocott (Ječný and Vojtěchová 1984; de 
Montpréville et al. 1999; Mörner et al. 1999) and hematoxylin and eosin (de Montpréville et al. 1999; Mörner et al. 1999). However, histological examinations are time consuming and expensive. Also reliable method of compression preparations of lungs is not performed at large scale.There is almost no information available about Emmonsia infection in game, pets, laboratory, domestic and farm animals therefore.

Village areas provide suitable living conditions for saprophytic stage of E. parva var. crescens and for possible transmitters of adiaspores, small rodents, and risk of the infection for humans and animals is not limited only to the forests.

\section{Adiaspory Emmonsia parva var. crescens $\mathbf{v}$ plicích drobných hlodavců na venkově}

Účelem studie bylo srovnání výskytu Emmonsia parva var. crescens v obydlené a neobydlené venkovské lokalitě (ve vesnici s 615 obyvateli a v okolních neobydlených lesích) na základě nálezů adiaspor v plicích drobných hlodavců chycených v těchto lokalitách. Adiaspory E. parva var. crescens byly nalezeny v plicích $13(9,6 \%)$ ze 135 vyšetřených hlodavců. Ze sedmi druhů hlodavců byly infikovány čtyři: norník rudý (Clethrionomys glareolus, 15,6 \%), myš domácí (Mus musculus, 5,6 \%), myšice křovinná (Apodemus sylvaticus, 3,2 \%) a myšice lesní (A. flavicollis, 16,7 \%). Prevalence byla ve vesnici nejvyšší u A. flavicollis, v lesích u $C$. glareolus. Intenzita infekce byla nízká nebo střední (méně než 100 adiaspor na zvíře). Infekce byla zjištována nejčastěji na jaře a pohlaví zvířat na ni nemělo vliv. Rostlinný kryt neobdělávané půdy ve vesnici, v němž se vyskytují stejné rostliny jako v okolních lesích, může podporovat jak výskyt hlodavců tak výskyt saprofytního stadia $E$. parva var. crescens. Nebezpečí nákazy pro lidi a zvířata proto není omezeno pouze na lesní (neobydlené) lokality.

\section{References}

ABT, K. F. 1992: Die Nahrung von Apodemus sylvaticus und A. flavicollis während eines Sommers im Gebiet der Bornhöveder Seenkette (Schleswig-Holstein). Säugetierkd. Inf., Jena, 3: 409-419

DE MONTPRÉVILLE, V. T., HUERRE, M., DULMET, E. 1999: Adiaspiromycose, 2 cas de diagnostic fortuit. Ann. Pathol. 19: 513-515

DVOŘÁK, J., OTČENÁŠEK, M., ROSICKÝ, B. 1973: Adiaspiromycosis caused by Emmonsia crescens, Emmons et Jellison 1960. Study of the Czechoslovak Academy of Sciences No.14, Prague, Academia, 120 p.

ENGLAND, D. M., HOCHOLZER, L.1993: Adiaspiromycosis: an unusual fungal infection of the lung. Report of 11 cases. Am. J. Surg. Pathol. 17: 876-886

FAUSTUS, L., POLÍVKA, F. 1976: Botanický klíč. $1^{\text {st }}$ ed., Prague, Státní pedagogické nakladatelství, 480 p.

FISCHER, O. A. 2000: Blowflies of the genera Calliphora, Lucilia and Protophormia (Diptera, Calliphoridae) in South-Moravian urban and rural areas with respect to Lucilia bufonivora Moniez, 1876. Acta Vet. Brno 69: 225-231

HALOUZKA, R., GROCH, L., PIVNÍK, L.1989: Z alba patologické morfologie: adiaspora z plic hraboše polního. Veterinářství 39: 2

HOLIŠOVÁ, V. 1960: Potrava myšice křovinné Apodemus sylvaticus L. na Českomoravské vrchovině. Folia Zool. 9: $135-158$

HUBÁLEK, Z. 1999: Emmonsiosis of wild rodents and insectivores in Czechland. J. Wildlife Dis. 35: 243-249

HUBÁLEK, Z., JUŔICOVÁ, Z., ZIMA, J. 1988: Adiaspiromycosis of mammals in an air-polluted area of Czechoslovakia. Ekológia, Bratislava 7: 281-289

HUBÁlEK, Z., KRŠKA, A., GAISLER, J., ZEJDA, J., HEROLDOVÁ, M., RYCHNOVSKÝ, B. 1997 . Emmonsiosis of small mammals (Rodentia, Insectivora) in southwest Moravia, Czech Republic. Folia Zool. 46: 223-227

HUBÁLEK, Z., NESVADBOVÁ, J., HALOUZKA, J. 1998: Emmonsiosis of rodents in an agroecosystem. Med. Mycol. 36: 387-390

HUBÁLEK, Z., NESVADBOVÁ, J., RYCHNOVSKÝ, B. 1995a: A heterogeneous distribution of Emmonsia parva var. crescens in an agro-ecosystem. J. Med. Vet. Mycol. 33: 197-200

HUBÁLEK, Z., RYCHNOVSKÝ, B., PEŠKO, J. 1995b: Adiasporomycosis of rodents inhabiting the shores of fishponds. Czech Mycol. 48: 139-144

JEČNÝ, V., VOJTĚCHOVÁ, A. 1984: Adiaspiromykóza drobných savců z Mostecké kotliny Severočeské hnědouhelné pánve. Sbor. Okres. Muzea, Most, 6: 11-21 
JOHNSTONE, A. C., HUSSEIN, H. M., WOODGYER, A. 1993: Adiaspiromycosis in suspected cases of pulmonary tuberculosis in the common brushtail possum (Trichosurus vulpecula). N. Z. Vet. J. 41: 175-178

KOĎOUSEK, R., VORTEL, V., FINGERLAND, A., VOJTEK, V., ŠERÝ, Z., HÁJEK,V., KUČERA, K. 1971: Pulmonary adiaspiromycosis in man caused by Emmonsia crescens: report of a unique case. Am. J. Clin. Pathol. 56: $394-399$

KŘIVANEC, K., DVOŘÁK, J., OTČENÁŠEK, M. 1976: Emmonsia crescens Emmons et Jellison 1960 - a rare causative agent of adiaspiromycosis in squirrels (Sciurus vulgaris L.) in the Czechoslovakia. Med. Parazitol., Moscow, 45: 464-467 (In Russian)

KŘIVANEC, K., OTČENÁŠEK, M. 1977: Importance of free living mustelid carnivores in circulation of adiaspiromycosis. Mycopathologia 60: 139-144

MÖRNER, T., AVENÄS, A., MATTSSON, R. 1999: Adiaspiromycosis in a European beaver from Sweden. J. Wildlife Dis. 35: 367-370

NUORVA, K., PITKÄNEN, R., ISSAKAINEN, J., HUTTUNEN, N. - P., JUHOLA, M. 1997: Pulmonary adiaspiromycosis in a two year old girl. J. Clin. Pathol. 50: 82-85

OOI, H. - K., LIN, S. - C. 1996: Adiaspiromycosis in Niviventer coninga in Taiwan. Taiwan J. Vet. Med. Anim. Husb. 66: $253-258$

PETERSON, S. W. SIGLER, L. 1998: Molecular genetic variation in Emmonsia crescens and Emmonsia parva, etiologic agents of adiaspiromycosis, and their phylogenetic relationship to Blastomyces dermatitis (Ajellomyces dermatitis) and other systemic fungal pathogens. J. Clin. Microbiol. 36: 2918-2925

PROKOPIČ, J., ŠTĚRBA, J. 1978: Spontaneous infection of white laboratory mice with Emmonsia crescens Emmons et Jellison, 1960 under natural conditions. Folia Parasitol. Prague 25: 371-374

RAJSKA-JURGIEL, E. 2000: Breeding dispersal in Clethrionomys glareolus females. Acta Theriol. 45: 367-376 VENČIKOV, A. I., VENČIKOV, V. A. 1977: Základní metody statistického zpracování dat ve fyziologii. $1^{\text {st }}$ ed., Prague, Avicenum, $160 \mathrm{p}$ 


\title{
SCREENING FOR PENICILLIN PLASMA RESIDUES IN CATTLE BY ENZYME-LINKED IMMUNOSORBENT ASSAY
}

\author{
H.J. LEE, P.D. RYU, H. LEE, M.H. CHO, M.H. LEE* \\ College of Veterinary Medicine and School of Agricultural Biotechnology, \\ Seoul National University, Suwon 441-744, Korea \\ Received June 19, 2000 \\ Accepted August 28, 2001
}

Abstract

Lee, H. J., P. D. Ryu, H. Lee, M. H. Cho, M. H. Lee:Screening for Penicillin Plasma Residues in Cattle by Enzyme-Linked Immunosorbent Assay. Acta Vet. Brno 2001, 70: 353-358.

In this study, we established a rapid prediction test for the detection of the cattle with violative tissue residues of penicillins. The recommended therapeutic doses of two penicillins, ampicillin (withdrawal time, 6 days) and amoxicillin (withdrawal time, 14 days), were administered to two groups of 10 cattle each. Blood was sampled and tested before drug administration and during the withdrawal period. The concentration of penicillins in plasma, determined by a semi-quantitative ELISA, was compared to that of internal standard ( $4 \mathrm{ppb}$ as penicillin $\mathrm{G})$. The absorbance ratio of internal standard to sample (B/Bs) was introduced as an index to determine whether drug residues in cattle tissues are negative or positive. That means $\mathrm{B} / \mathrm{Bs}$ ratio lower than 1 was considered residue positive and that higher than 1 negative.

All 10 plasma samples from non-treated cattle showed negative results for both penicillins. Both penicillins were detected in plasma samples of cattle treated until the 3rd day of withdrawal period.

The present study has shown that the semi-quantitative ELISA could be easily adapted for prediction of screening plasma residues for penicillin antibiotics (ampicillin and amoxicillin) in live cattle.

Penicillin ELISA, plasma, cattle contamination, live animal test

With the ever-growing world population, animal production practices have become more intensive and efficient, accompanied by increasing demands for drug treatment. Currently, approximately $80 \%$ of all food animals receive medication for part or most of their lives (Sternesjö et al. 1998). In the near future, nearly all animals bred in the world for food will receive chemotherapeutic and prophylactic agents of some type (Booth 1988). A survey of all violative carcasses in the United States in 1993 revealed that the most frequent drug residues were penicillin (20\%), streptomycin (10\%), oxytetracycline (10\%), and sulfamethazine (9\%) (Paige 1994). According to Canadian Animal Health Institute, penicillins were the most frequently detected residues in milk in most countries (Heeschen et al. 1996). Since 1986, Department of Veterinary Service, Ministry of Agriculture \& Forestry, Korea has conducted National Residue Program (NRP) to sample meat and poultry for residue tests at the slaughtering establishments under its inspection authority and from import shipments at the port of entry. In 1997, a total of 45,000 samples comprising 10,000 beef, 23,000 pork, and 11,000 poultry meat were analyzed for five kind of antibiotics (penicillins and tetracyclines) and six sulfonamides. The results showed violative residues of tetracyclines, sulfonamides and aminoglycosides in beef, pork, and poultry meat.

A few cases of minor allergic reactions (e.g., skin rashes) in individuals previously sensitized to penicillin $G$ residues in milk and meat have been documented, as well as strong evidence linking a widespread agricultural use of antibiotics to an increase in antibiotic resistance among the animal and human pathogens (Dewdney et al. 1984;

Address for correspondence:

$\begin{array}{ll}\text { Mun-Han Lee, DVM, Ph.D. } & \text { Phone: }+88-31-290-2741 \\ \text { Laboratory of biochemistry } & \text { Fax: +88-31-293-0084 }\end{array}$

College of Veterinary Medicine, Seoul National University

Suwon 441-744, Korea

E-mail: vetlee@ @snu-ack
Phone: +88-31-290-2741

http://www.vfu.cz/acta-vet/actavet.htm 
Franco et al. 1990; Huber 1971; Kindred et al. 1993; Mitchell et al. 1995; Ormerod et al. 1987).

The demands for reliable, simple, sensitive, rapid and low-cost methods for detecting residues in foods continue to grow (Mitchell et al. 1998; Lee et al. 2001). Variety of enzyme immunoassays have been developed and adopted for detecting the generic groups of chemical residues in milk, urine, blood, and meat samples (Gardner et al. 1996; Szekacs 1994; Lee et al. 2000; Lee et al. 2001). Enzyme-linked immunosorbent assay (ELISA) has become the most popular method for chemical residue detection in food due to its extreme sensitivity, simplicity, and ability to screen large number of samples (Clifford 1985; Gardner et al. 1996; Szekacs 1994; Lee et al. 2001).

In the present study, we developed a live animal test to predict the tissue residues of penicillins (ampicillin and amoxicillin) in cattle by examining the concentration of drug in blood during the withdrawal period obtained by an ELISA technique.

\title{
Materials and Methods
}

Materials

Ten Holstein female cattle ( 7 - 8 month old, mean body mass $200 \mathrm{~kg}$ ) were used in the experiments. Binotal Injection $(100 \mathrm{mg} / \mathrm{ml}$ ampicillin natrium) was obtained from Bayer Korea Ltd. (Seoul, Korea). Clamoxyl L.A. Injection ( $150 \mathrm{mg} / \mathrm{ml}$ amoxicillin trihydrate) was obtained from Pfizer Korea Ltd. (Seoul, Korea). ELISA kits for B-lactams, manufactured by Idetek, were purchased from Korea Media Ltd.

Drug administration and samples

Ampicillin was administered intramuscularly to each of the 10 cattle at the rate of $11 \mathrm{mg}$ per kg body weight per day for seven consecutive days, and amoxicillin twice ( $24 \mathrm{~h}$ interval) intramuscularly to each of $10 \mathrm{cattle}$ at $15 \mathrm{mg}$ per kg body weight. Blood samples were collected from all cattle before administration of the drugs and on days 1 , 3, 5, 6, and 10 after the last ampicillin injection. From the cattle treated with amoxicillin, blood samples were collected on days $1,3,7,10$, and 14 . Ten $\mathrm{ml}$ of blood from each cattle were collected in heparinized tubes and centrifuged at $4500 \times g$ for 10 minutes to collect the plasma.

Preparation of standard curves

Stock standard solution of $1000 \mu \mathrm{g} / \mathrm{ml}$ of each ampicillin and amoxicillin were prepared using USP standards in saline. These stock solutions were further diluted with saline or blank serum to prepare $0,1,2,5,10,20,50,100$, 500 , and $1000 \mu \mathrm{g} / \mathrm{ml}$ working standard solutions. Standard curves of each antibiotic were constructed using the standard solutions fortified into serum to determine the detection limit for the ELISA kit.

\begin{abstract}
Analysis of penicillins in plasma
ELISA tests for $\beta$-lactams were applied to each plasma sample in duplicate using a modified methodology described by B oi on et al. (1995), in which the manufacturer's protocol for milk screening was adapted for plasma screening. Briefly, $250 \mu \mathrm{l}$ of the internal standard solution (equivalent to $4 \mathrm{ppb}$ penicillin $\mathrm{G}$ ) was pippetted into a test tube containing immobilized $\beta$-lactam antibodies. The plasma $(250 \mu$, diluted $1: 10 \mathrm{w} / \mathrm{PBS})$ was pippetted into individually labeled tubes. An equal volume of tracer solution (enzyme conjugate, lyophilized horseradish peroxidase labeled $\beta$-lactam conjugate with preservative) was added, and the test tubes were incubated at room temperature for 3 minutes with continuous shaking. The excess sample and conjugate reactants were then washed out with saline. A colour developer ( $0.5 \mathrm{ml}$, enzyme substrate) made up of 2,2'-azino-bis(3-ethylbenzothiazoline6-sulfonic acid) and hydrogen peroxide in citrate buffer was added to the test tubes, and the mixture was incubated at room temperature for 3 minutes with continuous shaking. Dilute sodium dodecyl sulfate solution $(0.5 \mathrm{ml})$ was added to each test tube to stop the reaction. The absorbance was read at the wavelength of $405 \mathrm{~nm}$ with a photometric detector (Idetek Reader, Awareness Technology, Inc., USA, operated in the 0.9 ratio mode) and compared with that of the internal standard $(4 \mathrm{ppb})$. Samples with absorbance higher than that of the internal standard were considered to be negative ( $\beta$-lactam drug free), and those with absorbance lower than that of the internal standard were considered as positive. In this analysis, no more than 5 samples were processed simultaneously, and the assay was completed within 10 minutes (B ois on et al. 1995; Cullor et al. 1994).
\end{abstract}

\section{Results}

Standard curves and detection limits

The standard curves of ampicillin and amoxicillin were constructed to determine the detection limits of each drug. The detection limits of ampicillin and amoxicillin were found to be lower than 1 ppb based on the B/Bo ratio of 0.8 in the ELISA system (Figs. 1 and 2). 


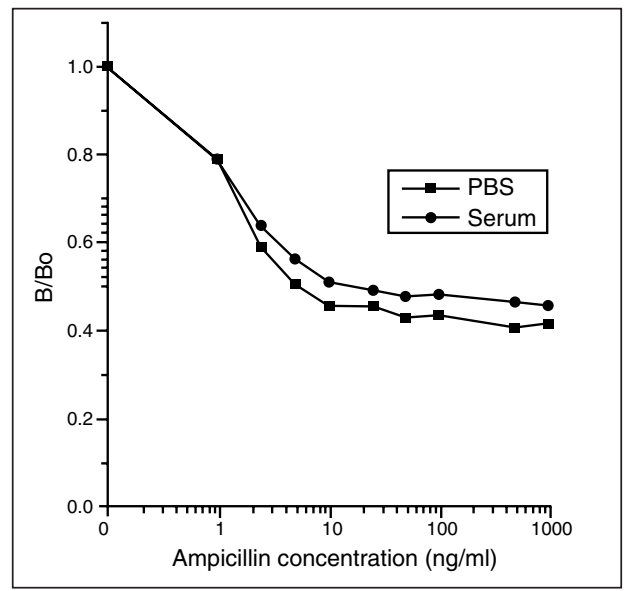

Fig. 1. Standard curves of ampicillin in phosphate buffer solution (PBS) and serum. Detection limit of ampicillin was calculated as less as $1 \mathrm{ppb}$. The detection limit of ELISA kit was determined as the point of the $\mathrm{B} / \mathrm{Bs}$ ratio of 0.8 . B/Bo: Absorbance ratio of the standard (Bo) and PBS or control serum (B).

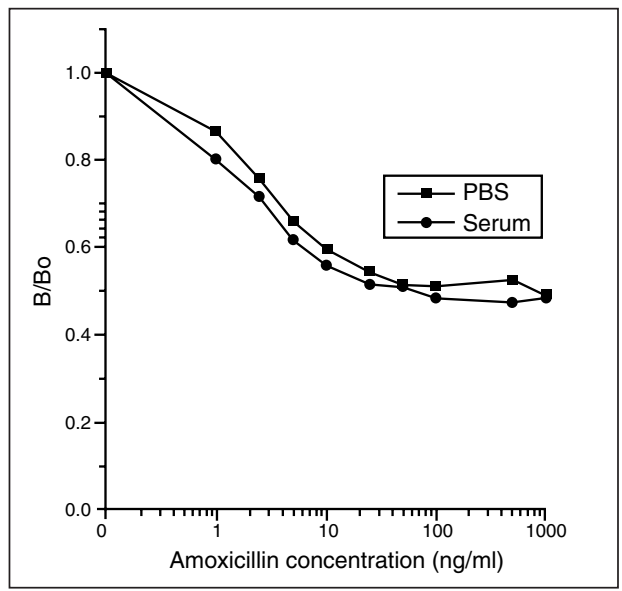

Fig. 2. Standard curves of amoxicillin in phosphate buffer solution (PBS) and serum. Detection limit of amoxicillin was calculated as less as $1 \mathrm{ppb}$. The detection limit of ELISA kit was determined as the point of the $\mathrm{B} / \mathrm{Bs}$ ratio of 0.8 . B/Bo: Absorbance ratio of the standard (Bo) and PBS or control serum (B).

\section{Live animal test for penicillins in plasma}

Ampicillin. Results of plasma analysis are shown in Table 1. As the absorbance ratios of normal 10 cattle of the control group were higher than 1.0, that is, the concentrations of ampicillin in the diluted plasma $(\times 10)$ of this group were higher than $4 \mathrm{ppb}$, the control group was negative. On day 1 of withdrawal, 8 of the 10 samples were found positive. The number of positive samples on day 3 was 5 . All samples showed negative reaction after day 5 of withdrawal $(\mathrm{B} / \mathrm{Bs}$ ratio $\geq 1.0)$.

Table 1

Depletion profile of ampicillin in plasma during withdrawal period

\begin{tabular}{|c|c|c|c|}
\hline $\begin{array}{c}\text { Withdrawal } \\
\text { (days) }\end{array}$ & $\begin{array}{c}\text { No. of } \\
\text { positive }\end{array}$ & $\begin{array}{c}\text { No. of } \\
\text { negative }\end{array}$ & $\begin{array}{c}\text { B/Bs ratio } \\
\text { (Mean } \pm \text { SEM) }\end{array}$ \\
\hline Control* $^{*}$ & 0 & 10 & $1.374 \pm 0.079$ \\
1 & 8 & 2 & $0.818 \pm 0.171$ \\
3 & 5 & 5 & $1.126 \pm 0.457$ \\
5 & 0 & 10 & $1.409 \pm 0.119$ \\
6 & 0 & 10 & $1.443 \pm 0.070$ \\
\hline
\end{tabular}

* Blood was collected before administration of ampicillin.

The drug was administered intramuscularly with $11 \mathrm{mg} / \mathrm{kg}$ body weight once daily for seven consecutive days, and blood samples were collected from cattle during the withdrawal period. Concentration of ampicillin in plasma was analyzed using a LacTek ELISA kit. B is absorbance of sample and Bs is absorbance of the internal standard (4 ppb). B/Bs ratio lower than 1.0 is considered positive and that higher than 1.0 negative.

Amoxicillin. Results of plasma analysis are shown in Table 2. As the absorbance ratios of normal 10 cattle of the control group were higher than 1.0, that is, the concentrations of amoxicillin in the diluted plasma $(\times 10)$ of this group were higher than $4 \mathrm{ppb}$, the group tested negative. All samples tested positive on day 1 of withdrawal. On day 3,4 of the 10 samples were positive. After day 5 of withdrawal, all samples showed negative reaction (B/Bs ratio $\geq 1.0)$. 
Table 2

Depletion profile of amoxicillin in plasma during withdrawal period

\begin{tabular}{|c|c|c|c|}
\hline $\begin{array}{c}\text { Withdrawal } \\
\text { (days) }\end{array}$ & $\begin{array}{c}\text { No. of } \\
\text { positive }\end{array}$ & $\begin{array}{c}\text { No. of } \\
\text { negative }\end{array}$ & $\begin{array}{c}\text { B/Bs ratio } \\
\text { (Mean } \pm \text { SEM) }\end{array}$ \\
\hline Control* & 0 & 10 & $1.405 \pm 0.145$ \\
1 & 10 & 0 & $0.760 \pm 0.082$ \\
3 & 4 & 6 & $1.255 \pm 0.173$ \\
5 & 0 & 10 & $1.436 \pm 0.171$ \\
7 & 0 & 10 & $1.472 \pm 0.150$ \\
10 & 0 & 10 & $1.413 \pm 0.081$ \\
\hline
\end{tabular}

* Blood was collected before administration of amoxicillin.

The drug was administered twice intramuscularly with $15 ? / \mathrm{kg}$ body weight at intervals of $24 \mathrm{~h}$ and blood samples were collected from cattle during withdrawal period. Concentration of amoxicillin in plasma was analyzed using a LacTek ELISA kit. B is absorbance of sample and $\mathrm{Bs}$ is absorbance of the internal standard (4 ppb). B/Bs ratio lower than 1 is considered positive and that higher than 1 negative.

\section{Discussion}

To prevent unwanted drug residues from entering the human food chain, both the government authorities and the industries have established extensive control measures (Sternesjö et al. 1998). A variety of rapid screening tests have been developed and applied for determining drug contamination of animal products on farms and slaughterhouses. The Swab Test On Premises (STOP), a nonspecific microbial inhibition test, has been used in abattoirs in the United States and Canada for over 10 years to screen for antibiotic residues in tissues from slaughtered animals (Korsrud et al. 1998). The test requires overnight incubation, and results are not ready until the following day.

Sweeney et al. (1993) developed a model with urine of pigs to predict the number of days for sulfamethazine concentration to fall below $0.1 \mathrm{ng} / \mathrm{g}$ of tissue residues in various organs. This prediction model provided the practical basis for current Sulfa On Site (SOS) test in which swine urine is used for screening sulfonamide residues in animal tissue in federally inspected abattoirs of the United States, Canada, and Korea. With the correlation between residue levels in tissue and urine established, the urine residue is used as an indicator of sulfamethazine in animal tissue. Though, unlike STOP and the Live Animal Swab Test, the SOS test provides same-day results, and it detects only sulfonamides. Papich et al. (1994) conducted experiments to determine whether penicillin residues in the plasma of live animals can be used as a practical indicator of penicillin residues in tissues of food-producing animals at slaughter. According to the results, penicillin $\mathrm{G}$ in the plasma did not correlate with that in tissues. To determine whether commercially available rapid tests can be used as screening tests to indicate the presence of penicillin $\mathrm{G}$ in the plasma of live animals, B oison et al. (1995) analyzed plasma from healthy steers injected with procaine penicillin $\mathrm{G}$ only, and a combination using benzathine penicillin $\mathrm{G}$ with four commercially available tests (Brilliant Black reduction test, LacTek test, Charm Farm test, and Charm Test II receptor assay). When results of the four rapid tests were compared with the results of liquid chromatographic method, none of the rapid tests gave false-positive results. With the administered dosage taken into consideration, plasma concentration profiles of penicillin antibiotics in our study were similar to the above studies.

As the withdrawal time of a drug is established based on the tolerance level in tissue and elimination rate of the drug, and blood is a central pool of drug distribution to body compartments and elimination from tissues through biological fluids (B ooth 1988), it may be help to predict the residue of drugs in tissue by examining the blood drug depletion profile 
during withdrawal period (Korsrud et al. 1995; B ois on et al. 1995; Lee et al. 2000; Lee et al. 2001). According to our results, the developed methods can be adapted easily to predetect residues of penicillin antibiotics (ampicillin and amoxicillin) in live cattle using diluted blood plasma $(\times 10)$ with the modified ELISA test kits.

It is conceivable that the veterinary inspector in the abattoir may be able to use this method to screen for penicillin antibiotics in plasma from live cattle in holding pens prior to slaughter and obtain same-day results. Cattle that show positive can then be held in the pens until retest results come up negative before they are slaughtered.

\section{Aplikace metody ELISA pro stanovení penicilínovích reziduí v krevní plasmě skotu}

V této studii byl vypracován postup pro detekci prchavých zbytků penicilínu v tkanivách skotu. Doporučované dávky dvou penicilínů, jmenovitě ampicilínu (doba odbourání 6 dní) a amoxicilínu (doba odbourání 14 dní) byly podány dvěma skupinám skotu $(\mathrm{n}=10)$. Krev byla odebrána a testována před podáním léků i počas jejich odbourávání. Koncentrace penicilínu $\mathrm{v}$ plasmě byla stanovena pomocí semikvantitativní metody ELISA a byla porovnána $\mathrm{s}$ koncentrací interního standardu (4ppb penicilínu G). Poměr absorbance interního standardu k absorbanci vzorky (B/Bs) byl definován jako index k určení či zbytek antibiotik ve tkáních byl pozitivní anebo negativní. Poměr B/Bs menší než 1 byl pokládán jako reziduálně pozitivní a poměr vetší než 1 jako reziduálně negativní.

Každý z deseti vzorků odebraných skotu, jemuž nebylo podáno žádne antibiotikum byl negativní na oba penicilíny. Oba však byly detekovány v plasmě zvířat do třetího dne od podání dávky.

Táto studie potvrdila, že semikvantitativní metoda ELISA může být snadno adaptována pro stanovení reziduí antibiotik penicilínové řady (ampicilínu a amoxicilínu) v krevní plasmě skotu.

\section{Acknowledgements}

This work was supported by the Brain Korea 21 Project and a grant from Agricultural Research and Promotion Center.

\section{References}

BOISON, J. O., KORSRUD, G. O., PAPICH, M. G., MACNEIL, J. D. 1995: Comparison of four commercially available rapid test kits with liquid chromatography for detecting penicillin $\mathrm{G}$ residues in bovine plasma. J. Assoc. Off. Anal. Chem. Int. 78: 1144-1152

BOOTH, N. H.1988: Veterinary pharmacology and therapeutics. In: BOOTH, N. H., MCDONALD, L. E.: Toxicology of drug and chemical residues. Iowa State University Press, Ames, Iowa, pp. 1149-1205

CUllor, J. S., VAN EENENNAAM, A., GARDNER, I., PERANI, L., DELLINGER, J., SMIT, W. L., THOMPSON, T., PAYNE, M. A., JENSEN, L., GUTERBOCK, W. M.1994: Performance of various tests used to screen antibiotic residues in milk samples from individual animals. J. Assoc. Off. Anal. Chem. Int. 77: $862-870$

DEWDNEY, J. M., EDWARDS, R. G. 1984: Penicillin hypersensitivity is milk a significant hazard?: a review. J. Rech. Soc. Med. 77: 866-877

FRANCO, D. A., WEBB, J., TAYLOR, C. E. 1990: Antibiotic and sulfonamide residues in meat: implications for human health. J. Food Prot. 53: 178-185

GARDNER, I. A., CULlOR, J. S., GALEY, F. D., SISCHO, W., SALMAN, M., SLENNING, B., ERB, H. N., TYLER, J. W.1996: Alternatives for the validation of diagnostic assays used to detect antibiotic residues in milk. J. Am. Vet. Med. Assoc. 209: 46-52

HEESCEN, W. H., SUHREN, G. 1996: Principles of and practical experiences with an integrated system for the detection of antimicrobials in milk. Milchwissenschaft. 51: 154-164

HUBER, W. G.1971: The impact of antibiotic drugs and their residues. Adv. Vet. Sci. Comp. Med. 15: 101-132

KINDRD, T. P., HUBBERT, W. T. 1993: Residue prevention strategies in the United States. J. Am. Vet. Med. Assoc. 202: 46-49

KORSRUD, G. O., SALIBURY, C.D. C., FESSER, A. C. E., MACNEIL, J. D. 1995: Laboratory evaluation of the Charm Farm test for antimicrobial residues in meat. J. Food Prot. 58: 1129-1132

KORSRUD, G. O., SALISBURY, C. D. C., RODES, C. S., PAPICH, M. G., YATES, W. D. G., BULMER, W. S., 
MACNEIL, J. D., LANDRY, D. A., LAMBERT, G., YONG, M. S., RITTERS, L. 1998: Depletion of penicillin $\mathrm{G}$ residues in tissues, plasma and injection sites of market pigs injected intramuscularly with procaine penicillin G. Food Addit. Contam. 15: 421-426

LEE, H. J., LEE, M. H., HAN, I. K. 2001: Application of ELISA for the detection of oxytetracycline residue in live animal. Asian-Aust. J. Anim. Sci. 14: 378-381

LEE, H. J., LEE, M. H., HAN, I. K. 2000: Application of ELISA for the detection of penicillin antibiotic residues in live animal. Asian-Aust. J. Anim. Sci. 13: 1604-1608

LEE, H. J., LEE, M. H., RYU, P. D., LEE, H., CHO, M. H. 2001: Enzyme-linked immunosorbent assay for screening the residues of tetracycline antibiotics in pigs. J. Vet. Med. Sci. 63: 553-556

LEE, M. H., LEE, H. J., RYU, P. D. 2001: Public health risks: chemical and antibiotic residues. Asian-Aust. J. Anim. Sci. 14: 402-413

MITCHELL, J. M., YEE, A. J. 1995: Antibiotic use and transfer of drug resistance: does it mean we should stop treating animals with these drugs? Dairy Food Environ. Sanit. 15: 484-487

MITCHELL, J. M., GRIFFITHS, M. W., MCEWEN, S. A., MCNAB, W. B., Yee, A. J. 1998: ntimicrobial drug residues in milk and meat: causes, concerns, prevalence, regulations, tests, and test performance. J. Food Prot. 61: $742-56$

ORMEROD, A. D., REID, T. M. S., MAIN, R. A. 1987: Penicillin in milk-its importance in urticaria. Clin. Allergy. 17: $229-234$

PAIGE, J. C. 1994: Analysis of tissue residues. FDA Vet. 9: 4-6

PAPICH, M. G., KORSRUD, G. O., BOISON, J. O., YATES, W. D., MACNEIL, J. D., JANZEN, E. D., MCKINNON, J. J., LANDRY, D. A. 1994: Disposition of penicillin G after administration of benzathine penicillin $\mathrm{G}$, or a combination of benzathine penicillin $\mathrm{G}$ and procaine penicillin $\mathrm{G}$ in cattle. Am. J. Vet. Res. 55: $825-30$

STERNESJÖ, L., JOHNSSON, G. 1998: A Novel Rapid Enzyme Immunoassay (Fluorophos BetaScreen) for Detection of B-Lactam Residues in Ex-Farm Raw Milk. J. Food Prot. 61: 808-811

SWEENEY, R. W., BARDALAYE, P. C., SMITH, C. M., SOMA, L. R., UBOH, C. E. 1993: Pharmacokinetic model for predicting sulfamethazine disposition in pigs. Am. J. Vet. Res. 54: 750-754

SZEKACS, A. 1994: Development of enzyme-linked immunosorbent assay (ELISA) systems for environmental monitoring. Acta Biol. Hung. 45: 77-80 
Plate III

Literák I. et al.: Avipoxvirus...pp. 339-344

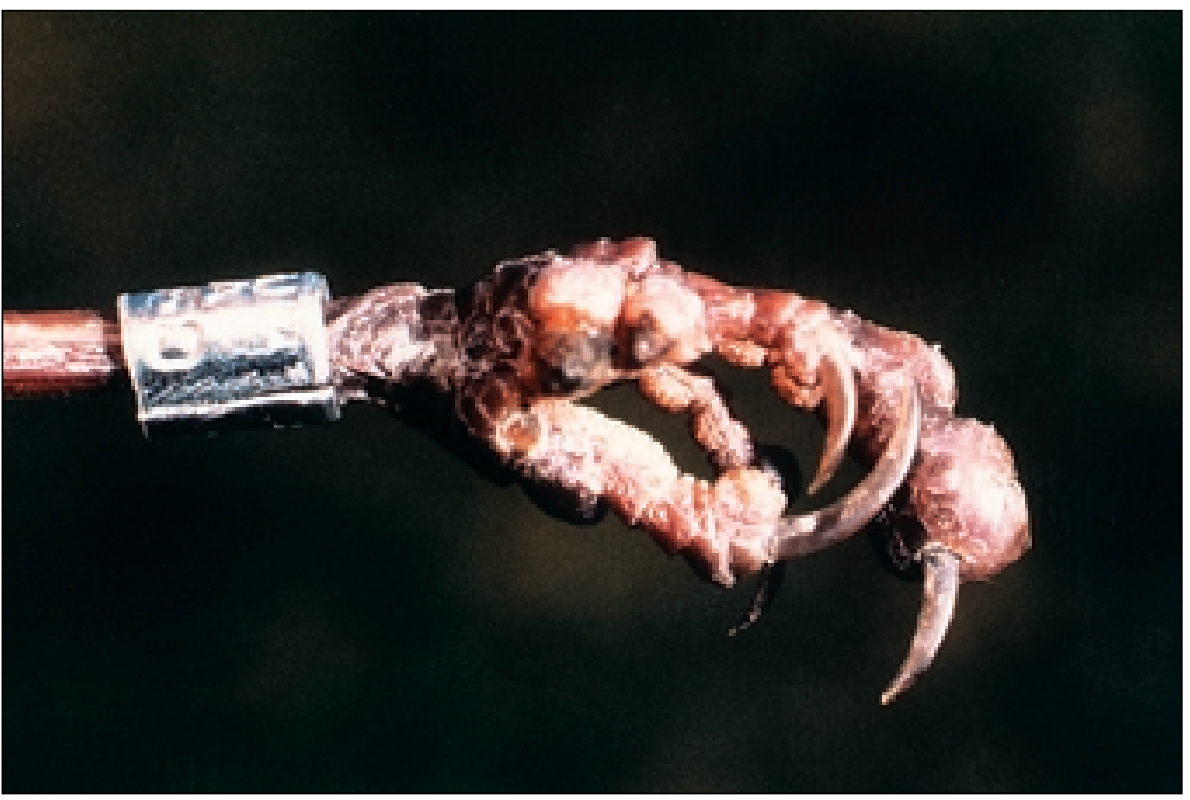

Fig. 1. Nodular avipoxvirus changes on the toes of Prunella modularis (Socovce, 5 August 1984). Photographed by M. Hromádko.

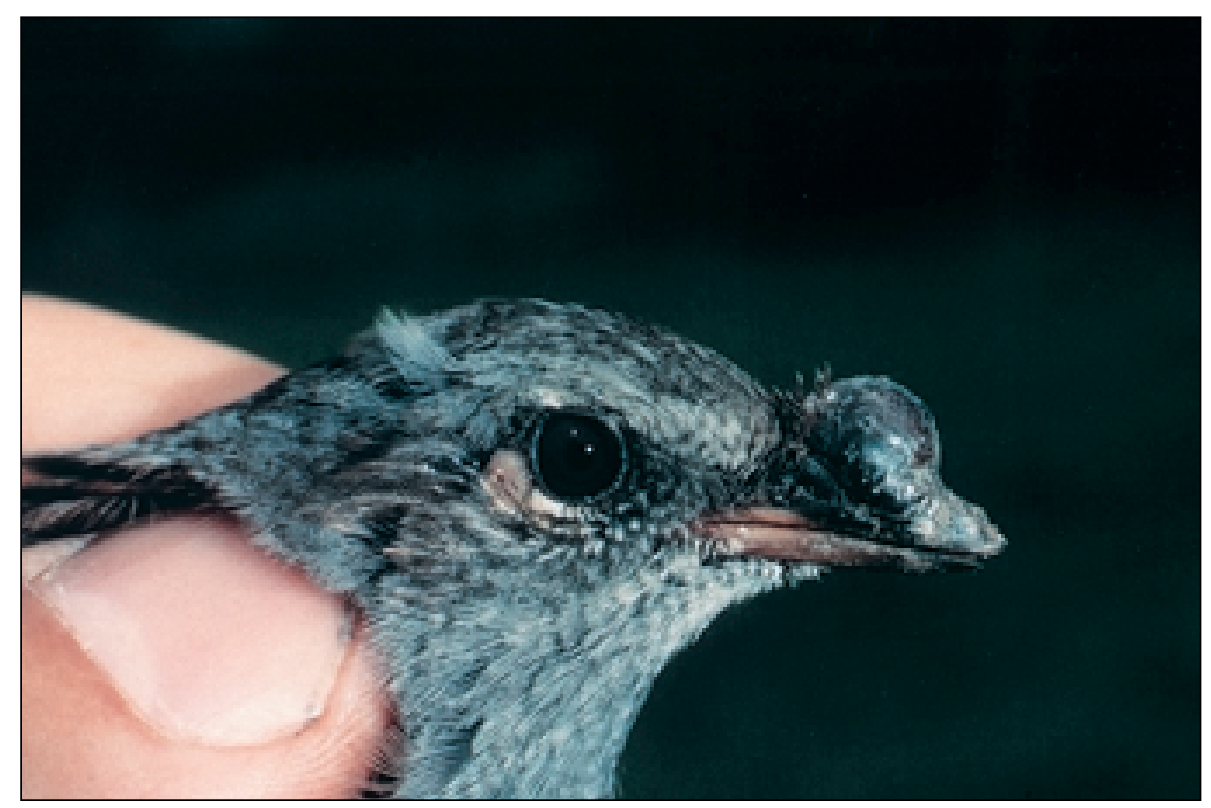

Fig. 2. Nodular avipoxvirus changes on the lower eyelid on the dorsal side of the beak of Prunella modularis (Socovce, 11 August 1984). Photographed by M. Hromádko. 


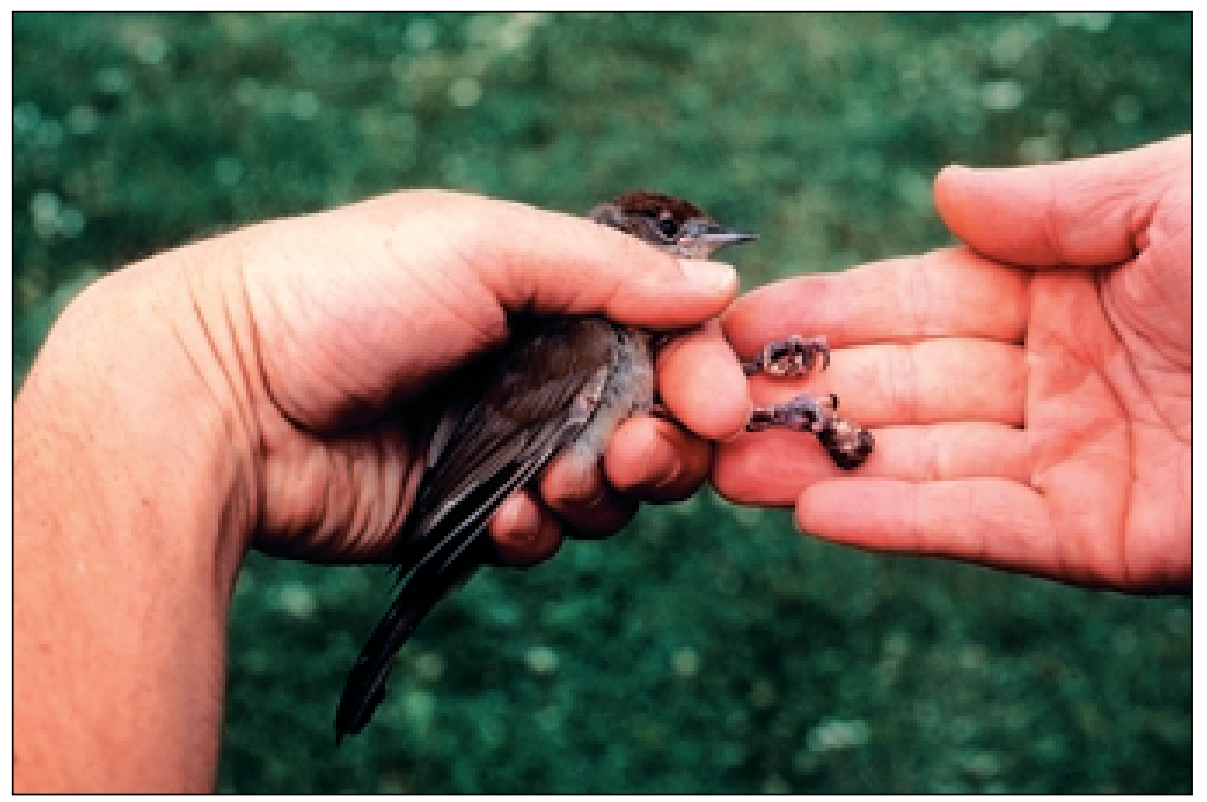

Fig. 3. Avipoxvirus changes on the eyelid, in the corner of the beak, on the distal end of the wing and on the toes of Sylvia atricapilla (Socovce, 27 July 1999). Photographed by I. Literák.

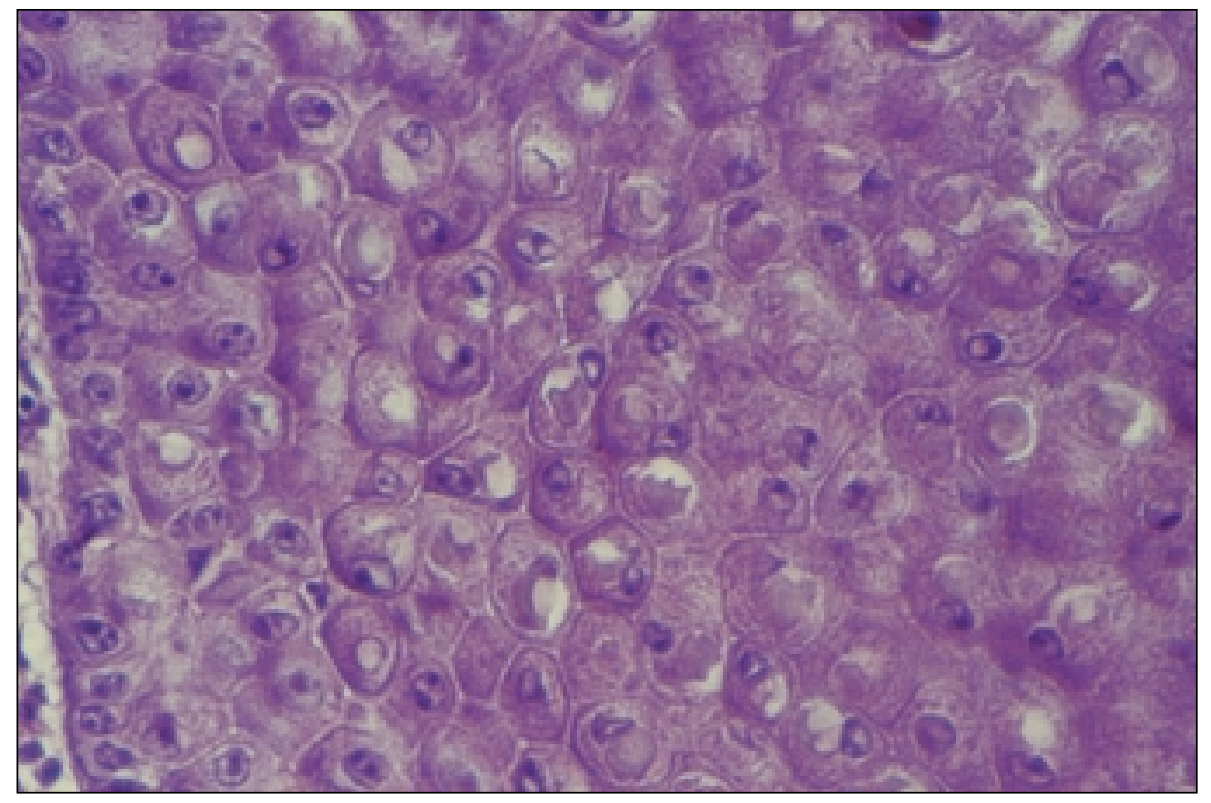

Fig. 4. Detail of hypertrophic keratinocytes with Bollinger bodies. Deep zone of epidermal nodular hyperplasia. On the right side inflammatory infiltrate in the dermis. (Sylvia atricapilla, Socovce, 27 July 1999, HE, $\times 500)$. Photographed by R. Halouzka. 